\title{
Reconstructing Aboriginal History and Cultural Identity through Self Narrative: A Study of Ruby Langford's Autobiography Don't Take Your Love to Town
}

\author{
Pariksha Kumari \\ Freelance Researcher \\ M.A. English \\ HP University \\ Shimla, India \\ pariksharana24@gamil.com
}

\begin{abstract}
The last decades of previous century has witnessed the burgeoning of life narratives lending voice to the oppressed, dispossessed, and the colonized marginalities of race, class or gender across the world. A large number of autobiographical and biographical narratives that have appeared on the literary scene have started articulating their ordeals and their struggle for survival. The Aboriginals in Australia have started candidly articulating their side of story, exposing the harassment and oppression of their people in Australia. These oppressed communities find themselves sandwiched and strangled under the mainstream politics of multiculturalism, assimilation and secularism.
\end{abstract}

The present paper seeks to analyze how life writing serves the purpose of history in celebrated Australian novelist, Aboriginal historian and social activist Ruby Langford's autobiographical narrative, Don't Take Your Love to Town. The Colonial historiography of Australian settlement has never accepted the fact of displacement and eviction of the Aboriginals from their land and culture. The whites systematically transplanted Anglo-Celtic 
culture and identity in the land of Australia which was belonged to the indigenous for centuries. Don't Take Your Love to Town reconstructs the debate on history of the colonial settlement and status of Aboriginals under subsequent government policies like reconciliation, assimilation and multiculturalism. The paper is an attempt to gaze the assimilation policy adopted by the state to bring the Aboriginals into the mainstream politics and society on the one hand, and the regular torture, exploitation and cultural degradation of the Aboriginals recorded in the text on the other. In this respect the paper sees how Langford encounters British history of Australian settlement and the perspectives of Australian state towards the Aboriginals. The politics of mainstream culture, religion, race and ethnicity, which is directly or indirectly responsible for the condition of the Aboriginals, is also the part of discussion in the paper.

Keywords: Aboriginals, Colonial Politics, Multiculturalism, Assimilation, Aboriginal Culture, Anglo-Celtic Culture, Identity, Dispossession, Race and Ethnicity.

The last decades of previous century has witnessed the burgeoning of life narratives lending voice to the oppressed, dispossessed, and the colonized marginalities of race, class or gender across the world. A large number of autobiographical and biographical narratives that have appeared on the literary scene have started articulating their ordeals and their struggle for survival. The Aboriginals in Australia have started candidly articulating their side of story, exposing the harassment and oppression of their people in Australia. These oppressed communities find themselves sandwiched and strangled under the mainstream politics of multiculturalism, assimilation and secularism. Present paper is an attempt to analyze the autobiographical narrative of Ruby Langford's Don't Take Your Love to Town that presents an alternative to the official history of Australia written by the early colonizers and explorers. That text strongly questions the imperial settlement of Australia particularly in terms of prolonged racial dominance that not only evicted the Aboriginals from their culture and land 
rights but also prejudiced the subsequent policies of immigration, assimilation or multiculturalism etc. Since, history and racial politics has been the part and partial of her social work her, Don't Take Your Love to Town, published in 1988, on the bicentenary of Australia, recommends strong re-evaluation of the history of its 'Christian heritage' and European's behavior with the Aboriginals in general and with women in particular. The text in form of a personal account brings out a staunch critique of colonial myth of the peaceful settlement, imperial expansion of racial culture in the continent and mid twentieth century racial discrimination and struggle of Aboriginal women to survive in multiple level of marginalization in Australia. It revives those early days of imperial explorations of new places, systematic encroachment of Aboriginals land resources, their conspired assassinations and imposition of white culture on the world's one of the oldest Indigenous cultures. In this sense, the narrative refutes Australia as a democratic country where the Aboriginals enjoy equal rights like other immigrants. In fact, entire process of the transplantation of European culture in Australian land dreamed by the imperial policy of the British. "What was first established in Australia was a transplantation of British culture. The culture of course, evolved away from its British source but the primary identification remained with 'British' culture" (Stratton and Ang, 147-148).

Ruby Langford belongs to the Sydney based Koorie community of Australia and Don't Take Your Love to Town records her personal experiences, as Aboriginal women, in twentieth century Australia. It is a real story of an Aboriginal women's struggle to survive her family of nine children. The novel reflects the life journey of a single Aboriginal family, yet it represents the larger Indigenous struggle in a society divided between black and white cultures. The narrative exposes the entrench racism of the colonized Australia of 1980s highlighting her experiences of life in bush camps and subsidized housing. It also portrays the daily life struggle of many aboriginal people doing back breaking menial jobs not considered 
suitable for white women. Commenting on the present condition of Aboriginals in Australia Ruby Langford argues, "we Kooris are fifteen to twenty years behind everyone else in all the basic human rights such as health, housing, employment and education; even the people who migrate here are on a higher social level than we are, and we're the first people of this land" (Quoted by Brewster, xi).

Before the advent of Europeans in Australia, the Aboriginals lived in approximately 500 tribes, each associated with its own language. Although these tribes had certain differences with each other in size but they had much in common. They had common myths and rituals which connected them with their ancestors, whom they regarded as the creators of the world and none of whom ever died but merged with the natural world and thus, remained a part of the present. These myths and rituals were known as dreaming or the dreamtime which signified their communion with the nature, the world and the past. This traditional life and culture of the Australian Aboriginals were disintegrated and annihilated when the European settlers arrived in the continent in 1770 and declared their centuries' old habitation as “terra nullius [that means no man's land]. With the passage of time Anglo British culture was transplanted on the land of the Aboriginals. The colonizers systematically made rules and the Aboriginals were evicted from their land abrogating their right over property. "Europeans took Aboriginal's land, states, Larissa Behrendt, destroyed the balance of the environment, destroyed the hunting grounds and ceremonial sites, stopped access to waterholes, and depleted resources for food and medicine. This led to inevitable conflict as Aboriginal people attempted to defend their traditional territories and their ways of life (111). Later the colonial historians very candidly and shrewdly spread message that the Australia was settled peacefully. "One of the gaping holes in ethnic Australian history" opines Jon Teo, "has been the lack of serious engagement with Aboriginal history: the failure to think through the issues of dispossession and racial relation between ethnic and indigenous groups..." (150). In this 
context the Aboriginal writers, Sally Morgan and Rubby Langford etc. through their personal as well as imaginative narratives not only refutes the colonial version of Australian historiography but also offer an alternative version of Aboriginal existence and its systematic destruction by the British colonizers.

In Don't take Your Love to Town Gnibi articulates all her personal history and experiences; history of gender discrimination, history of the annihilation of native culture and personal sorrows. She shows her grief saying that our" children were stolen to be trained in servitude to the whites....It was also cultural genocide, the destruction of Aboriginal identity, ....Still people don't want to know about this shameful history or about what's happening in the present ( My Bundjalung People, 40-41). Aboriginal voices have largely been silenced by excluding them from the historical constructions. However, "In Australia, most of the students are fed on the diet of lies and invisibility, comments Jakie Huggins, about the true history of this country from a very young age'(120). Gnibi strongly neglects this monopolistic version of stressing on the truth of Aboriginal life. "I am not interested in fiction" she argues and she is interested in "writing the truth about my people... This is from our side of the fence....Although the history of the whole of White Australia is one of the biggest fictions, aye? (Interview, 102).

In Don't Take Your Love to Town presents the staunch critique of assimilation policy brought by government in 1970s. The novel describes how the government tries to destroy the Koories heritage by assimilation policies this leads to the feelings of loneliness, dispossession and displacement for the aboriginals. The acts and laws imposed on the life of the Aboriginals, on the name of assimilation, controlled the "indigenous people", "socially and economically - determined their marriage partners, removed children from their parents, determined their living environments, barred them from certain places, controlled their access to employment, refused them access to institutions catering to non-indigenous people, limited 
their entrepreneurial activities in mainstream society and monitored their movements" (Sabbioni, xxiii). Many Aboriginals believe that the assimilation policies resulted in a total loss of Aboriginal cultural identity. "Not one Aboriginal family in whole of the Australia has gone untouched by these policies" (Sabbioni xxvii). They have no control over natural resources and live in outskirts of the town. Gnibi describes the politics of white government responsible for the pathetic life of the aboriginals. She expresses her grief, "I felt that I was living tribal but with no tribal was around me, no close-knit family. The food-gatherings, and the laws and the songs were broken up, and my generation at this time wandered around as if we were tribal but in fact living worst than poorest of the poor white, and in the case of women living hard because it seemed" (96).

Langford categorically addresses the implication of 'Assimilation Policy' over the culture and identity of the Aboriginals. It appears in the narrative that the assimilation ultimately turned to be unsuccessful. She argues that, "the government policy of assimilation by absorption meant splitting up the Aboriginals communities and I understand what this policy meant as I had four daughters and only one married an Aboriginal. My grand children are blond and blue or hazel, and within two or three hundred years there won't be Aboriginals in suburbia" (176).

The text realizes that the Aboriginal cultural identity has systematically been uprooted from their land. In Aboriginal culture there were no rules for property and no permission was required to meet friends and relatives. In fact, that they have collective ways of living without preferring materialism and business in terms of European civilization. But under the state system of governance, dominated by the whites, Aboriginals were not only evicted from their cultural values but also prevented meeting with their relatives and friends without the permission of commission made by the state government. "You weren't able to have anyone come and stay without permission of the commission. It reminded me of the 
missions. The rule was useless in our culture, where survival often depended on being able to stay with friends and relatives (174)". In the text the freedom and environment loving Aboriginals are seen doing menial jobs in houses of the whites. Throughout the book the Aboriginals can be observed struggling in the bushes for earning two times bread.

The novel also delineates how Aboriginal people were taken away from their land have sense of displacement throughout their lives. It imprints in their minds that they have to move from one mission to another mission, station and village to another searching for ill paid odd jobs such as fencing, process work in factories, servants and cleaners. Ruby Langford also works in tents, cars, tin houses and the Aboriginal Protection houses depending on the place where she and her partner could find a job. She could not develop a sense of home. Even she also applied for Aboriginal home lone but application was rejected. She wrote a poem feeling a sense of home;

A home

A home is where the heart is

Or so they say.

I wonder if I will own one

some sunny day

or will all my efforts be in vain.

And the whole battle be too much a strain

And put me in too much pain

Hence I shall refrain from this endless strain

And pitch a tent (217-18)

In Don't take Your Love to Town Ginbi the life of Gnibi as a woman is affected by sexism and racism. The Aboriginal women are still considered "black velvet" means sexually available. Many a time's women do not go to report the cases because they scare the judicial 
system run by the white community. In her other novel My Bundjalung People Rub's friend Pammy, an aboriginal artist, says: Can you imagine what it's like for a Koori woman, raped and beaten, to have to go for help to the same organization that stole kids initially and the same lot about her so called rights and protection? She knows she has not got any. (50).

The text also highlights the transcending phase of the Aboriginals women in urban and semi-urban areas in the 1980s. It was largely different from the life they had lived and experienced in the past. The colonization and state politics have affected and di srupted their traditional lives resulting vicious poverty for the urban Aboriginal. Ruby Langford's appears to be passed through myriad of socio-economic problems. The text reveals the fact that how disintegration of traditional Aboriginal livelihood has brought the evils of alcoholism and drug addiction among the males. In the words of Ann Brewster, "Due to factors such as the disintegration of traditional family and kinship structures, alcoholism and the high incidence of Aboriginal men in jail, in recent generations women have come to occupy a more prominent role in communal and family life" (Brewster 9). In this context Anne also quotes Roberta Sykes who states “... at least three out of every four black women will sleep alone, will bring up children without the benefit of black paternal presence, and will have no black male with whom to share their lives" (9). In the case of Ruby consumption of alcohol by her various husbands brings disastrous change in her life. Sharing her experiences with her male partners she says that, "the men loved you for a while and then more kids came along and the men drank and gambled and disappeared" (Langford 96). The personas like Sam Griffin, Gordon Campbell, Peter Langford and Lance Marriot who came in Ruby's life as husbands, fathered nine children with her. As far as the rearing of the children was concerned it was she who always took their responsibility. Ruby herself admits that she had done "gut-busting work" all her life (Langford 264). In order to survive and rearing her children Ruby did several jobs ranging from felling trees and cutting logs at George Creek to making fences at 
various places like Nindigully, Toobeah, Talwood and so on. She did hard physical labour even during pregnancies. Many a times she earned two times bread alone while her partners would drink and leave her without a word. Finally when the last man leaves, it is Ruby who takes on the responsibility of keeping her family alive.

The addiction of drugs and excess of alcohol results into domestic violence and she suffers in the hands of her various husbands like Sam, Gordon, Peter, Lance. Sam beats her accusing her for having affair. When she questions him "What are you talking about Sam... With that he knocked me to the ground and started to throttle me..." (59). Lance tortures her "...he belted me in the mouth and busted my false Teeth..., my lip was cutting open and pouring"(144). Peter is irresponsible and insensitive towards the family and gambles. She remarks the life as "... living worse than the poorest of poor whites, and in the case of women living hard because it seemed like the men loved you for a while and then more kids came along and the men drank and gambled and disappeared" (96). This all led her to take alcohol " No money no land no jobs no hope. So we had to find ways to keep our spirit up and that didn't mean our spiritual ones but also our liquid ones". (151).

The Aboriginal women in the text appear to be exploited by the black and white males. "Violence in Aboriginal women's lives had been two-fold - intra-racial and interracial. Interracial violence was faced, mostly by those Aboriginal women in urban and semi urban settings, who worked as domestic helpers in white households" (Pal,188). The white settlement was purely based on the concept of capitalism; hence the Aboriginals were used as the cheap laborers available on low wages. This concept entirely trapped the males of aboriginal communities into the addiction of drugs and alcoholism. It largely impacted the lives of Aboriginal women who had to shoulder the burden of the family life. Don't Take Your Love to Town significantly unravels the interracial complications that hit Ruby's life by and large. Ruby passes through such experiences at Gunnedah Hill when her first partner 
Sam Griffin tortures her after the birth of their son Bill. Here she meets Aboriginal women at Gunnadah Hill who have had the similar experiences of domestic violence. When she meets Nerida for the first time, Ruby explains, "I hardly saw Nerida without black eyes and bruises. ... My existence wasn't better, and I had my share of black eyes and bruises later" (Langford 58). Ruby's first partner Sam was always very suspicious kind of person who always kept his eyes on her and "running around on" her (Langford 59). The same episode reveals the worst condition of Aboriginal women when he knocks Ruby to the ground and tried to throttle her. He belts Ruby so much that she decides to go to Bonalbo, her home town, and that is where he left her. When she finds Lance cheating she immediately reactes and Lance in a anger hits her hard breaking her duplicate teeth. It harms her lips and blood begins pouring out profusely. Ruby gets hospitalized, and has her face remained swollen for many weeks. However, Lance is arrested. But this incident brings a significant change in her life and she decides that she has tolerated "enough of bashings and being knocked around generally" and would tolerate it no more (Langford 144). She never forgives Lance and starts living life on her own terms and conditions. When asked by her son-in-law when she would get married again, she replies, "When I can get a man who can look after me better than I can do myself" (Langford 170).

Ruby Langford is a strong Aboriginal woman who not only daringly challenges the colonially set rules in her land but also takes part role as a responsible mother. She always cares her children and teaches them to be bold against exploitation and racism. She shares many instances when she appears as shield for her children and endorses them in personal as well as other aspects of life. She narrates an incident when she finds her daughter Aileen "doubled up in the middle of the road near the flat" (Langford 206). When she asks what has happened to her then Aileen informs Ruby that her husband Dennis has kicked her with his heavy shoes in the stomach. On hearing that Ruby got furious and ran across the road and 
opens the door where Dennis was sitting drunk. Ruby then says: "He said something but I didn't give him time to answer. I belted him and knocked him over the lounge and flattened him. I didn't raise my daughter to be bashed and kicked by bastards like you ${ }^{e e}$ I threw him out. I don't know where I got the strength from (206).

Ruby Langford lived in 'Allawah', the Aboriginal Hostel in Granvilie, she describes the place, "for people who'd raised their families and didn't want to become live- in babysitters for the kids (Langford, 267). Here racism and exclusion results into the sense of identity and displacement. In the text Aboriginal characters are tried to make silent but they are vocal enough to defend themselves. When Ruby lived in Green Valley and was offended by the complaints of her neighbor, Mrs. Jenkin about the noise, she objects, "Come outside and fight as good as you can talk and complain,' I said, 'while you bastards were having your kids in comfort. I was battling to raise mine in a tent where my husband had left me with gutful of his next child-you don't own the land your house is on, my people were here first, so get off, come and fight me if you're game you bitch"(176).

Ruby, as Koori origin, has not any lived experiences with Aboriginal community. Most of her life she has not lived with the aboriginal women in the bush. She has only seen semi-urban aboriginal women working as a laborers and workers in the white settlements. In the traditional system of Aboriginal life women used to be treated different than they have been made to live in the culture of Australia. She feels cultural identity distorted by the British culture. Ruby's describes her purpose of writing this book as, to "know who [she] was," and secondly, to "give some idea of the difficulty [Aboriginal women like her] have surviving between two cultures" (Langford 269). The Aboriginal womanhood painted by her reconstructs the identity and cultural values of Aboriginal life style. She portrays the implications of the Aboriginals' contact with western civilization. Her narrative of self is evidently unfolds the history of Aboriginal women who have been sandwiched under the 
clash of the Black and White cultural clashes. Her writing and social activism strongly unfolds the hidden layers of colonial project where the Aboriginal history and culture was never given importance. Through her writing she presents how the 'Assimilation Policy' brought up by the Australian state has harmed the Aboriginality by and large.

The Aboriginal communities have been misrepresented in the mainstream literature. These narratives disseminate the centuries old life experiences of their victimization under colonial as well as cultural politics. Verbalizing their social awakening through writings they strive to explode the concrete wall of hegemony and oppression and spread a message of hope reclaiming their dignity, identity and a respectable place in society. Today, the Aboriginals are not puppets in the hands of their oppressors but valiant fighters who can fight the politics of silence. In conclusive paragraph of Don't Take Your Love to Town Gnibi seems very desirous to ameliorate the relationship between the Aboriginals and the whites. She hopes that Aboriginal narratives will create empathy among the whites and one day the Aboriginals will enjoy their rights and respectful life on their motherland. "I knew when I finished this book a weight would be lifted from my mind, not only because I could examine my own life from it and know who I was, but because it may help better the relationship between the Aboriginal about the white people. That it might give some idea of the difficulty we have surviving between two cultures, that we are here and will always be here. (269). 


\section{Works Cited}

Behrendt, Larissa. Indigenous Australia for Dummies. Willey Publishing House, 2012.

Brewster, Anne. Reading Aboriginal Women's Life Stories. Sydney University Press, 2006.

Huggins, Jackie. Sister Girl. University of Queensland Press, 1994.

Langford, Rubby. Don't Take Your Love to Town. Penguin Books, 1988.

--- My Bundjalung People. University of Queensland Press, 1998.

Paul, Payal. Tiddaism: Negotiating Aboriginality and the Experiences of the Australian Aboriginal Woman in a Cross-Cultural Context. https://postscriptum.co.in/wpcontent/uploads/2019/07/pS4.iiPayel.pdf Accessed on 15, December 2020.

Sabbioni, Jennifer. "Preface.” Indigenous Australian Voices: A Reader. Eds. Jennifer Sabbioni, Kay Schaffer and Sidonie Smith. Rutgers University Press, 1998. pp i-xxv.

Stratton, Jon and Ien Ang. " Multicultural Imagined Communities”: Cultural Differences and National Identity in the USA and Australia". Multicultural States: Rethinking Difference and Identity. Edit David Bennett. Routledge, 1998.

Teo, Jon. "Multiculturalism and the Problem of Multicultural Histories: An Overview of Ethnic Historiography". Cultural History in Australia. Ed. Hsu-Ming Teo and Richard White. University of New South Wales Press, 2003. pp 142-55. 